A N N A L E S

UNIVERSITATIS MARIAE CURIE-SKŁODOWSKA

LUBLIN - POLONIA

VOL. XXXI, 2

SECTIO J

2018

Uniwersytet Marii Curie-Skłodowskiej w Lublinie. Wydział Pedagogiki i Psychologii

\title{
MONIKA HAJKOWSKA
}

ORCID: 0000-0001-5524-4246

monika.hajkowska@poczta.umcs.lublin.pl

\section{Higiena w pogladach Romualda Plaskowskiego (1821-1896)}

Romuald Pląskowski's Views on Hygiene (1821-1896)

\section{STRESZCZENIE}

Romuald Pląskowski kierował wskazówki higieniczne w szczególności do kobiet. Widział w nich osoby odpowiedzialne za wychowanie zdrowotne dzieci oraz prowadzenie domu zgodnie z zasadami higieny. Autor podejmował zagadnienia związane z pielęgnacją potomstwa. Radził m.in. w kwestii kąpieli, doboru odzieży, pożywienia, snu i rozwoju fizycznego dzieci. Ponadto uświadamiał kobiety, jak powinny dbać o własne zdrowie, aby jak najdłużej się nim cieszyć, oraz wprowadzał w tajniki diety i sposoby przyrządzania posiłków. Zwracał też uwagę na wyposażenie domowej apteczki (w tym samodzielne przygotowywanie ziół i naparów) oraz podkreślał wpływ warunków mieszkaniowych na zdrowie rodziny.

Słowa kluczowe: higiena; zdrowie; dieta; kobieta; wychowanie; Romuald Pląskowski

\section{WPROWADZENIE}

W XIX w. kształtowano świadomość zdrowotną w społeczeństwie polskim dwutorowo - poprzez edukację oraz prasę. Zasady higieniczne starano się wpajać w sposób praktyczny, właściwie organizując nauczanie i kładąc nacisk na warunki sanitarne szkół. Higienę popularyzowano również poprzez publicystykę oraz edycję poradników adresowanych do rodziców, nauczycieli, ludności poszczególnych stanów. Postęp medycyny, a szczególnie bakteriologii, miał wpływ na podejmowane działania służące poprawie stanu społeczeństwa polskiego, edukacji i profilaktyce. Na ziemiach Królestwa Polskiego podjęto szereg przedsięwzięć higienicznych i sanitarnych, których inicjatorami byli lekarze i higieniści. Były to 
m.in. kolonie letnie, wystawy, wykłady i odczyty (Demel 1964, s. 33-51; Demel 1980, s. 21-33; Ostrowska 1988, s. 251-269; Podgórska-Klawe 2005, s. 21-108; Arabas 2006, s. 224-243; Marek 2009, s. 77-81; Bołdyrew 2016, s. 66-71).

Zgodnie z Encyklopedya Powszechna Stanisława Orgelbranda (1863, s. 371) „higiena” to „część medycyny, ucząca żyć zgodnie z prawami natury, dla zachowania zdrowia i przedłużenia życia". Podobne wyjaśnienie znajdujemy w Encyklopedyi Ilustrowanej Medycyny i Higieny Popularnej (1892, s. 142): „(...) część medycyny, podająca prawidła, w jaki sposób należy prowadzić życie, aby utrzymać zdrowie, a nawet nadwątlone poprawić, a tem samem zapobiedz pojawianiu się choroby". Termin ten miał bardzo szerokie znaczenie. Lekarze i higieniści odnosili go do wielu dziedzin życia człowieka oraz instytucji zdrowia publicznego (Wielka Encyklopedya Powszechna Ilustrowana 1902, s. 593-606).

Jednym z lekarzy podejmujących w swoich dziełach zagadnienie higieny był Romuald Pląskowski. Urodził się 7 lutego 1821 r. w dobrach rodzinnych Czarne, w powiecie Lipno. Jego ojcem był Kajetan Pląskowski, prezes Towarzystwa Kredytowego Ziemskiego w guberni płockiej, zaś matką - Józefa z Trembeckich. W 1845 r., po zakończeniu edukacji w gimnazjum płockim, rozpoczął studia lekarskie w Dorpacie, które ukończył 5 lat później. Swoją wiedzę poszerzał, studiując w Niemczech, Francji i Anglii. W 1854 r. przyjechał do Warszawy i podjął pracę w Szpitalu św. Rocha na Krakowskim Przedmieściu. Był internistą oraz pełnił funkcję ordynatora. Ponadto był związany z Wojskowym Szpitalem Ujazdowskim (1855-1856) oraz ze Szpitalem św. Jana Bożego w Warszawie (1859-1889). Szczególnie interesowała go psychiatria. W 1858 r., dzięki zleceniu Komisji Rządowej Spraw Wewnętrznych i Duchownych, studiował ją w licznych klinikach na świecie, m.in. we Francji, Niemczech, Belgii, Holandii, Szwajcarii, Austrii. Swoją pasją do medycyny, a szczególnie psychiatrii, dzielił się ze studentami i pracownikami Akademii Medyko-Chirurgicznej w Warszawie, w której od 1862 r. prowadził wykłady. Wraz z powstaniem Szkoły Głównej Warszawskiej został mianowany na stanowisko adiunkta, a od 1864 r. był profesorem nadzwyczajnym. Likwidacja tej szkoły nie przerwała jego pracy naukowej. Od 1869 r. kontynuował ją na Cesarskim Uniwersytecie Warszawskim jako docent psychiatrii i dyrektor kliniki psychiatrycznej. W 1887 r. odszedł na emeryturę. Pląskowski pełnił również funkcję eksperta sądowo-lekarskiego w dziedzinie psychiatrii. Ponadto był członkiem Towarzystwa Lekarskiego Warszawskiego (od 1854 r.) oraz Rady Lekarskiej Królestwa Polskiego (1866-1867). Zajmował się także działalnością pisarską, przedstawiał wyniki swoich badań i rozważań naukowych. Najbardziej interesowała go problematyka psychiatrii. Z zakresu tej dziedziny napisał dwutomowy podręcznik pt. Psychiatria, w którym dodatkowo zawarł słownik terminów medycznych. Publikował też na łamach czasopisma medycznego „Gazeta Lekarska” (był w niej współredaktorem) oraz w „Pamiętniku Towarzystwa Lekarskiego Medycznego". Artykuły zamieszczał także w Encyklopedii Rolnictwa. Jego za- 
interesowania dotyczyły też tematu higieny i dietetyki, co zaowocowało cyklem artykułów opublikowanych na łamach czasopisma „Bluszcz”. Zmarł 24 czerwca 1896 r. w Warszawie (Chojna 1981, s. 705-706; Kośmiński 1888, s. 391-392; Ś.p. dr Romuald Pląskowski 1896, s. 9; Ś.p. Romuald Pląskowski 1896, s. 23). Przed śmiercią ustanowił testament, zgodnie z którym Towarzystwo Lekarskie Warszawskie wypłacało autorom nagrody pieniężne za najlepsze prace z psychiatrii. Na ten cel przeznaczył 4000 rubli. Zbiory swojej prywatnej biblioteki przekazał Towarzystwu (Bojczuk 2005, s. 284).

Celem artykułu jest prezentacja poglądów Pląskowskiego na temat higieny. Lekarz, w trosce o zdrowie społeczeństwa polskiego, popularyzował wiedzę w zakresie zdrowego stylu życia, racjonalnego odżywiania, kosmetologii, przyczyn powstawania chorób i sposobów ich leczenia oraz wodolecznictwa i ćwiczeń fizycznych. Był przekonany o potrzebie znajomości zasad higieny zarówno przez kobiety, jak i mężczyzn. Pisał:

(...) hygiena dziś podniosła się do rzędu wiadomości obowiązujących w ukształceniu ogólnem i stanęła na tej wyżynie, do jakiej tylko dojść może i nauka, pełna prawd wyższych, opartych na doświadczeniu, wpływająca znakomicie na udoskonalenie rodu ludzkiego. (...) umiejętnie zastosowane zasady higieny do życia codziennego przyczynią się przeważnie do uniknienia wielu błędów. (...) Chciejmy tylko zgłębiając prawdy przyrody, przejąć się ważnością przedmiotu... (Pląskowski 1865c, s. 7).

Pląskowski stał na stanowisku, że wiedza z tego zakresu pozwoli na rozwiązanie wielu problemów zdrowotnych.

\section{W TROSCE O ZDROWE DZIECKO}

Pląskowski zapoznawał swych czytelników z zagadnieniem zawierania małżeństw. Podkreślał, aby nie bagatelizować wieku kobiety i mężczyzny, ich dojrzałości do związku. Małżonkowie nie mogli być ze sobą spokrewnieni. Przeszkodą w zawarciu małżeństwa były niebezpieczne choroby dziedziczne występujące w rodzinach, m.in. suchoty, padaczka, zołzy, reumatyzm (Pląskowski 1876, s. 314-315).

Wiele miejsca w swoich publikacjach autor poświęcił opiece nad małym dzieckiem. Matkę czynił odpowiedzialną za jego wychowanie od pierwszych dni po urodzeniu. Podkreślał znaczenie kąpania noworodka w temperaturze od 27 do 28 stopni Réaumura' ${ }^{1}$ Encyklopedia Powszechna PWN 1985, s. 854). Zdaniem le-

1 Skala Réaumura - skala temperatur zaproponowana w 1730 r. przez fizyka i przyrodnika René Antoine'a Ferchaulta de Réaumura, której punkt $0^{\circ}$ odpowiada temperaturze zamarzania chemicznie czystej wody, a punkt $80^{\circ}$ - temperaturze jej wrzenia. 
karza powinna ona trwać nie dłużej niż 10 minut (Pląskowski 1869b, s. 103-104). Poza tym zalecał mycie główki mydłem lub wodą z sodą. Radził systematyczne usuwanie łoju z części ciemieniowej oraz stałe utrzymywanie jej w czystości. W czynności tej konieczne było używanie delikatnych przedmiotów (np. gąbek, grzebieni) (Pląskowski 1866a, s. 99). Ciało dziecka zalecał wycierać miękkimi pieluszkami z perkalu lub płótna. Podkreślał znaczenie higieny pępka i szczególną jego ochronę (Pląskowski 1869b, s. 104). Przestrzegał rodziców przed przegrzaniem niemowlęcia, dlatego zalecał wietrzyć skórę głowy i używać czystej bielizny. Pląskowski zwracał uwagę na rodzaj tkaniny, z której były wykonane ubrania. Jako niewskazane oceniał zbyt ciepłe (takie jak bawełna, wełna) oraz krochmalone. Krytykował zakładanie ciasnych nakryć głowy oraz wiązanie kokard uciskających ciało dziecka. Z kolei na spacerach uwrażliwiał na wiatr, który mógł się przyczynić do zaziębienia (Pląskowski 1866a, s. 99). Istotną kwestią było ułożenie potomstwa do snu. W tym celu proponował kołyskę, łóżeczko lub posłanie wspólne z matką. Uświadamiał rodziców, że powinni zapewnić dziecku bezpieczeństwo podczas snu. Zarazem obalał stereotypy związane z koniecznością ciasnego owijania dziecka w becik i ograniczaniem jego ruchu. Jego zdaniem przyczynia się to do deformacji ciała i chorób dziecięcych oraz wpływa na system nerwowy maleństwa (Pląskowski 1869d, s. 176). W kwestii diety dziecka był zwolennikiem mleka naturalnego. Dopuszczał jednak wyjątkowe sytuacje, które stanowiły przeszkodę w karmieniu piersią, takie jak np. choroba kobiety. Wówczas zalecał mleko krowie, ogrzane do temperatury $30^{\circ} \mathrm{R}$, które matka mogła podawać porcelanową łyżeczką. Z obawy przed grzybicą jamy ustnej dziecka odradzał używanie smoczków kauczukowych, gumowych lub wykonanych z innych materiałów. Lekarz uczył kobiety planowania karmienia, w regularnych odstępach czasu i z przerwą w nocy na sen i odpoczynek (Pląskowski 1869c, s. 112). Był przeciwny powierzaniu dzieci nieodpowiedzialnym mamkom lub piastunkom. Jego zdaniem nie wolno bagatelizować długotrwałego płaczu niemowlęcia, ponieważ z uwagi na przepływ krwi do mózgu może to być niebezpieczne dla jego zdrowia i życia (Pląskowski 1869b, s. 104).

W swoich artykułach Pląskowski apelował do rodziców, aby unikali częstego kołysania dzieci i ich podrzucania. Zwyczaje te mogą bowiem powodować wstrzymanie oddechu, omdlenie, a nawet wymioty. Noszenie dziecka stale na jednym ramieniu uważał za szkodliwe. Dochodziło wówczas do skrzywienia kręgosłupa i utrudnień w przepływie krwi do mózgu. Niebezpieczne dla zdrowia potomstwa było przystawianie zabawek blisko oczu, szczególnie tych błyszczących. Maluch musi wtedy wytężać wzrok i pobudza tym samym nerwy wzrokowe. Skutkiem takich praktyk mogą być wady wzroku (np. zez). Pląskowski ostrzegał rodziców, że te codzienne zwyczaje mogą prowadzić do wielu chorób nerwowych. W opiece nad dzieckiem zalecał spokój i czujność. Dozwalał stopniowe oswajanie go z otoczeniem, w tym z żywiołami, które budzą strach (m.in. wodą, ogniem, wiatrem). 
Przykładowo w trakcie burzy radził główkę niemowląt przykrywać chusteczką, zamykać okiennice lub zasłaniać zasłony. Był przeciwnikiem opowiadania bajek najmłodszym dzieciom o duchach czy potworach, ponieważ tego typu historie na długo zapadają w pamięci i wyobraźni dziecka, mogą być źródłem lęków i w konsekwencji utrudniać codzienne funkcjonowanie córki lub syna $\mathrm{w}$ domu. $\mathrm{W}$ ich efekcie problemem mogło być wejście do ciemnego pokoju, spacer w lesie czy pobyt w nieznanym miejscu. Lekarz uświadamiał szczególnie matki, aby troskliwiej dbały o delikatny umysł dziecka (Pląskowski 1866b, s. 136). Zapoznawał rodziców z etapami rozwoju malucha oraz ze wskazaniami dotyczącymi wychowania fizycznego, moralnego i intelektualnego. Był przeciwnikiem rozpoczynania nauki zbyt wcześnie, dlatego podkreślał znaczenie dojrzałości fizycznej dziecka. Jego zdaniem edukacja intelektualna powinna być prowadzona bez uszczerbku dla zdrowia ucznia (Pląskowski 1876, s. 317). Argumentował, że „zdrowy i silny umysł znajduje tylko swą potęgę w zdrowem i nieschorzałem ciele" (Pląskowski 1869a, s. 32). Uświadamiał rodziców w kwestii budowy ciała ludzkiego i temperamentu. Zalecał dbałość o narządy odpowiedzialne za rozwój zmysłów. Uważał, że oczy należy chronić przed mocnym słońcem, gwałtownymi ruchami, zaś uszy - przed hałasem i zimnem. Na zmysły smaku i dotyku miały zły wpływ m.in. pikantne pokarmy, tytoń, alkohol oraz tabaka (Pląskowski 1876, s. 319-321).

\section{PIELĘGNACJA URODY KOBIETY I MĘŻCZYZNY}

W poglądach Pląskowskiego nie zabrakło zaleceń w kwestii kosmetologii. Udzielał on wskazówek kobietom na temat pielęgnacji twarzy i dbałości o urodę. Podkreślał ich naturalność i wdzięk, wskazując, że ładnie zarysowane brwi i rzęsy uwydatniają piękno kobiecych oczu. W jego opinii środki kosmetyczne do makijażu szpecą, czyniąc przedstawicielki płci pięknej karykaturalnymi. Poza tym substancje w nich zawarte mogą powodować podrażnienie oczu lub skóry, a niekiedy przyczyniają się również do pogorszenia wzroku. Biorąc to pod uwagę, zalecał ich używanie jedynie na scenie teatralnej, a nie w codziennym życiu. W przypadku niedoskonałości cery w postaci piegów, zmian skórnych czy pozostałości po takich chorobach, jak np. ospa, zalecał jednak wizytę u lekarza. Krytycznie odnosił się do produktów reklamowanych na łamach prasy, prawdopodobnie mających zbawienne działanie na tego typu dolegliwości. Apelował do kobiet o krytycyzm i zdrowy rozsądek. Naiwna wiara w skuteczność tych środków mogła bowiem przynieść opłakane skutki, tj. utratę urody. Pląskowski proponował używanie domowych kosmetyków do pielęgnacji, w tym szczególnie zalecał mycie twarzy w letniej i zimnej wodzie. Paniom borykającym się z tłustą cerą sugerował używanie wody z sodą, ponieważ taka mikstura ma działanie ściągające i matujące. Mydło migdałowe zalecał kobietom z cerą suchą, ponieważ cechuje je działanie nawilżające. Co istotne, obmywania twarzy powinny, jego zdaniem, odbywać się 
zarówno rano, przynajmniej na godzinę przed wyjściem na świeże powietrze, jak i wieczorem, tuż przed spoczynkiem. Ponadto lekarz uwrażliwiał płeć piękną na szkodliwe działanie słońca, wiatru oraz zmiany temperatury. Każda dbająca o swą urodę kobieta powinna chronić twarz kapeluszem, woalką, parasolką, zaś ręce rękawiczkami. W przypadku, gdy doszło mimo tego do zaczerwienienia skóry, jej łuszczenia lub podrażnienia, podpowiadał użycie wody migdałowej, laurowej lub cynkowej, ołowianej. Zarazem radził pozostanie w domu aż do ustania objawów. Szczególnie narażone na działanie promieni słonecznych są osoby o jasnej karnacji twarzy. Efektem ubocznym są piegi. Doświadczony lekarz mógł poradzić sobie z tym defektem, ale wymagało to czasu i niewątpliwie cierpliwości pacjenta (Pląskowski 1866c, s. 147-148).

W ramach pielęgnacji urody kobiety powinny ostrożniej korzystać z żelazek do układania włosów. Ich stosowanie osłabia strukturę włosów i przyczynia się do ich wypadania. Pląskowski krytykował też stosowanie spinek i papilotów, które przy nieodpowiednim nawilżeniu kosmyków mogą powodować ich łamliwość i utratę koloru. Podobnie wypowiadał się na temat pudrów oraz loków i warkoczy przypinanych do głowy, a także peruk - zarówno dla kobiet, jak i mężczyzn. Zwracał uwagę na jakość tych ostatnich, w tym szczególnie na ich czystość. Dodatkowo w swych artykułach lekarz poruszył zagadnienie produktów do pielęgnacji tłustej i suchej skóry głowy. Uświadamiał, że uniwersalne produkty i metody postępowania w tych przypadkach nie są wskazane (Pląskowski 1866a, s. 100).

Pląskowski, podejmując problem wypadania włosów, przytoczył opinię dra Pincusa, docenta z Berlińskiego Uniwersytetu. Wskazał na przyczyny tego stanu, m.in. na środki kosmetyczne szczególnie chętnie używane przez mężczyzn, takie jak spirytus, woda kolońska i olejek rycynowy. Stosowane zbyt długo, mogą drażnić skórę głowy i przyczyniać się do wypadania włosów. Zauważył, że kondycja włosów nie zawsze wynika ze złego stanu zdrowia człowieka. Nierzadko osoby zdrowe i silne cierpiały bowiem na przedwczesne łysienie. Pacjentom radził wizytę u lekarza. Podkreślał, że prawidłowo przyjmowane leki mogą przynieść pozytywne rezultaty, ale konieczna jest stała kontrola medyczna (Pląskowski 1871a, s. 251-252). W przypadku dzieci zalecał wpajanie właściwych nawyków higienicznych i pielęgnacyjnych. Zbyt częste czesanie włosów uważał za niewłaściwe. Krytykował stosowanie gęstych lub ostrych szczotek oraz uwrażliwiał przed wyrywaniem włosów podczas wykonywania fryzury. Dziewczęta, jego zdaniem, powinny czesać się w warkocz. W razie stanu zapalnego na skórze głowy za konieczną uznawał wizytę u specjalisty (Pląskowski 1871b, s. 259-260; Pląskowski 1871c, s. 265-266).

Codzienna toaleta dotyczyła również pielęgnacji zębów. Pląskowski zauważył, że dzieci, młodzież, a nawet osoby dorosłe lekceważą zasady higieniczne, które pozwalają utrzymać je w dobrym stanie do późnych lat życia. Niekiedy dochodziło do gryzienia twardych przedmiotów, co z kolei nadwyrężało ich stan 
i było przyczyną chorób. Lekarz podkreślił, że ból zębów pojawia się bardzo często przy gorączce, bólach głowy i gardła jako objaw dodatkowy. Ponadto poruszał w swych tekstach zagadnienie czyszczenia zębów, w tym z użyciem mocnych kwasów, niszczących szkliwo. Nie omijał tematów związanych z leczeniem zębów i dziąseł. Domowe kuracje, jego zdaniem, bywały mało skuteczne, dlatego zalecał wizytę u specjalisty (Pląskowski 1868r, s. 172; Pląskowski 1868s, s. 180).

Niebagatelną rolę w higienicznym stylu życia odgrywa codzienny ubiór. Ma on według Pląskowskiego wpływ na samopoczucie i zdrowie człowieka. Istotna jest tkanina, z której została wykonana odzież. Publicysta informował i jednocześnie ostrzegał, że do jej wyprodukowania używa się często szkodliwych barwników, które mają niekorzystne działanie. Ponadto podkreślał, że ubrania należy dobierać stosownie do pory roku, wieku i wygody. Pląskowskiemu nie był obcy temat mody. Wychodził z założenia, że w dążeniach za nowymi trendami należy zachować rozsądek i ich ślepo nie naśladować. Krytykował przesadę w zabieganiu o każdą nowość z zagranicy. Przybliżał swym czytelnikom zagadnienie ubrań regionalnych i charakterystycznych dla państwa, miasta czy stanu pochodzenia mieszkańców. Jego zdaniem miały one zastosowanie w określonym miejscu i czasie oraz nie mogły być wybierane przez każdego. Kobietom radził, aby ubranie dobierały do okazji. Zakładając długie, wytworne suknie w powszedni dzień narażały się bowiem na ośmieszenie i stanowiły przykry widok dla innych (Pląskowski 1865a, s. 40). Autor wyrażał zrozumienie dla płci pięknej kierującej się chęcią przypodobania czy wzbudzenia podziwu. Sugerował jednak rozsądek i kierowanie się zdrowiem, a nie wyłącznie modą ze światowych salonów. Ciasne suknie i gorsety uważał za szkodliwe, deformujące ciało, powodujące problemy z krążeniem krwi, a nawet choroby organów wewnętrznych (wątroby, śledziony, żołądka). W wyborze strojów dla pań zalecał tzw. złoty środek. Kobieta powinna budzić zachwyt i być ozdobą salonu, ale przede wszystkim nie może szkodzić sobie i własnemu zdrowiu. Dlatego apelował, aby uświadamiać panie, co powinny zakładać, aby swym pięknem budzić zachwyt otoczenia i jak najdłużej zachować zdrowie (Pląskowski 1865b, s. 74-75).

\section{CHOROBY I LEKI}

W pracach doświadczonego lekarza nie zabrakło tematu leczenia chorób. Czytelnika zapoznawał z ich rodzajami. Nie tylko wyjaśniał przyczyny zachorowań czy sposoby przeciwdziałania im, ale także opisywał objawy i leczenie oraz podawał zalecenia dotyczące opieki nad chorym. Wśród czynników mających wpływ na pojawienie się chorób wyróżnił: warunki życia, klimat, błędy żywieniowe, brak ruchu i higieny, dziedziczność. Zwracał uwagę na choroby zaraźliwe, takie jak cholera, tyfus, ospa, odra, czerwonka, krup, a nawet syfilis i choroby odzwierzęce. Apelował, aby w ich przypadku szczególnie dbać o higienę, izolację 
pacjenta i tym samym uniknięcie epidemii. W procesie leczenia chorób bezwzględnie wymagał opieki medycznej dla pacjenta (Pląskowski 1876, s. 322-332).

Pląskowski swymi artykułami wprowadzał czytelników w zagadnienie przygotowania podręcznych domowych apteczek. W jego przekonaniu każda gospodyni powinna zadbać o zaopatrzenie jej w potrzebne lekarstwa i zioła. Uważał, że w sytuacjach trudnych, kiedy ktoś z członków rodziny lub domowników cierpi, można temu zaradzić, podając odpowiednie środki dozwolone do użycia w domu. Niekiedy na wizytę lekarza trzeba było poczekać i wówczas preparaty z domowej apteczki mogły pomóc np. uśmierzyć ból. Ubolewał nad tym, że współczesne kobiety rzadko samodzielnie zbierają zioła i wolą się zaopatrywać w nie w aptekach, kupując tym samym preparaty sprowadzane z zagranicy (Pląskowski 1867a, s. 72; Pląskowski 1867c, s. 184). Chcąc udogodnić obywatelom ziemskim proces zaopatrzenia domowych apteczek, Pląskowski podał listę środków, które zostały dopuszczone do użycia domowego. Zaznaczył, że zgodnie z rozporządzeniem władz każdy obywatel posiadający taką apteczkę jest zobowiązany zawiadomić o tym najbliższego lekarza rządowego, który ma za zadanie czuwać nad bezpieczeństwem oraz kontrolować sposób przechowywania i podawania środków (Pląskowski 1867b, s. 180; Pląskowski 1873a, s. 46-47). Publicysta zarazem przybliżył czytelnikowi kalendarz prac potrzebnych do przygotowania apteczki. W miesiącach zimowych, takich jak styczeń i luty, zalecał sporządzać proszki, maści i plastry stosowane przy stłuczeniach, ranach. Niskie temperatury powietrza sprawiają bowiem, że materiały, z których się je wytwarza (m.in. korzenie, żywica), są bardziej kruche (Pląskowski 1867/1868, s. 7-8). W kwietniu i maju radził zbierać np. kwiaty fiołków, bratków, konwalii, pączki topoli i sosny, korzenie tataraku (Pląskowski 18681, s. 111-112; Pląskowski 18681, s. 128; Pląskowski 1868m, s. 136). Czerwiec wiązał się ze zbiorem owadów (takich jak czerwiec polski, mucha hiszpańska) oraz roślin (m.in. kwiatów róży, malwy, maku polnego) (Pląskowski 1868n, s. 163-164). Z kolei lipiec to miesiąc zbioru lipy, dziewanny, rumianku, lawendy, melisy, mięty, łopianu oraz innych ziół i owoców (Pląskowski, 1868a, s. 192; Pląskowski, 1868b, s. 204). W sierpniu gospodynie mogły zaopatrzyć się w sporysz, mąkę żytnią, chaber lekarski, len, gorczycę czy pestki wiśni (Pląskowski 1868c, s. 216; Pląskowski 1868d, s. 220). Wrzesień to zbiory jesienne, m.in. owoców bzu, jałowca, berberysu, korzeni goryczki żółtej, kozłka lekarskiego oraz igieł sosnowych (Pląskowski 1868e, s. 248; Pląskowski 1868f, s. 255-256). W październiku autor polecał zbieranie korzeni takich roślin, jak paproć, ślaz włoski, perz biały, piwonia lekarska (Pląskowski 1868o, s. 276; Pląskowski 1868p, s. 284). W listopadzie proponował przygotowanie wina (Pląskowski 1868g, s. 303-304; Pląskowski 1868h, s. 312; Pląskowski 1868i, s. 319-320; Pląskowski 1868k, s. 343-344). Co istotne, publicysta omawiał przy tym właściwości ziół, sposoby ich suszenia oraz metody sporządzania so- 
ków. Podkreślał, jak bardzo ważna jest czystość w trakcie przeprowadzania tego procesu, a także zachowanie właściwych miar i wag. Czytelnicy otrzymywali zatem dokładne przepisy i instrukcje przygotowania produktów leczniczych.

\section{WYJAZDY „DO WÓD”}

W popularyzacji zdrowia Pląskowski odwoływał się do balneologii. Zabrał głos m.in. w kwestii wód mineralnych. Popularyzował korzystanie z zakładów zdrojowych, w tym tworzonych w miejscowościach, w których nie było ujęcia źródeł wody mineralnej. Kuracje w zagranicznych uzdrowiskach były z reguły dosyć drogie i nie każdego pensjonariusza było stać na opłacenie kosztów wyjazdu i pobytu. Tańszą alternatywą były zakłady położone bliżej miejsca zamieszkania. Jego zdaniem kuracje w takich zakładach mają dobroczynne działanie na organizm człowieka. Niezależnie od wyboru miejsca ośrodka twierdził, że zachowanie pacjenta, w tym stosowanie się do zaleceń lekarza, ma olbrzymi wpływ na efekty kuracji. Apelował, aby każdy przyszły kuracjusz skonsultował z lekarzem, w jaki sposób ma korzystać z wód mineralnych. Konieczne było zwłaszcza dokładne określenie leczenia, m.in. rodzaju wody, jej ilości i temperatury, częstotliwości jej picia oraz diety. $Z$ uwagi na indywidualne potrzeby pacjenta odradzał korzystanie z zaleceń, do których stosowała się inna osoba (Pląskowski 1866g, s. 164). Publicysta podkreślał znaczenie właściwej organizacji dnia podczas kuracji - indywidualnej dla każdego. Ponadto zwracał uwagę na stosowny strój (do kąpieli wodnych i spacerów). Cenił wygodę, dlatego zalecał, aby każde ubranie, niezależnie do zastosowania, nie krępowało ruchów ani nie tamowało krążenia krwi. Przestrzegał przed wyszukaną i wykwintną kuchnią. Radził sięgać po proste dania, bez dużej ilości przypraw i sztucznych dodatków. W jadłospisie mogły się znaleźć takie produkty, jak mięso drobiowe, wołowe lub cielęce. Wykluczał jednak mięso kacze, gęsie oraz dziczyznę. $Z$ ryb proponował słodkowodne, ale nie tłuste. Był przeciwnikiem w diecie gatunków morskich, m.in. żółwi, homarów, langust, krewetek. Zachwalał jarzyny w menu, przede wszystkim młode, takie jak groszek zielony, marchew, ziemniaki, szpinak, kalafior czy szparagi. Odradzał spożywanie buraków, szczawiu oraz surowych sałat, karczochów i ogórków. Apelował o ostrożność w trakcie wybierania owoców, szczególnie surowych. Z kolei dania zimne, takie jak galarety czy potrawy z dodatkiem majonezu albo lody, powinny być zakazane. Do picia autor zalecał wodę oraz małe ilości lekkiego piwa lub białego wina. Dopuszczał spożycie kawy po obiedzie, natomiast odradzał herbatę (Pląskowski 1866h, s. 172). Zdaniem Pląskowskiego kolacja powinna być delikatna, a nawet skromna w ilości i jakości potraw. Uświadamiał kuracjuszy, że trawienie ma duży wpływ na efekty leczenia. Dlatego po wypiciu wody mineralnej (zwłaszcza gazowanej lub gorącej i ciężkiej) zalecał lekki posiłek i wypoczynek. Przestrzegał jednak przed poobiednim snem, który może 
nawet zagrażać życiu. Podobny pogląd wyraził na temat gwałtownego ruchu po posiłkach. Pacjentom w zakładach zdrojowych radził wybierać spacery oraz jazdę konną, o ile regularnie uprawiali ten sport. Co ciekawe, Pląskowski pozytywnie oceniał udział kuracjuszy w teatrze amatorskim, a krytykował rozrywki związane $\mathrm{z}$ hazardem. W godzinach wieczornych proponował umiarkowany, spokojny taniec. Podkreślał znaczenie snu w leczeniu pacjenta (Pląskowski, 1866i, s. 8). Omawiając różne przykłady działania wód na organizm kuracjusza, udowadniał, że jedynie rozsądek, dyscyplina i jego cierpliwość mogą przynieść korzyści w kuracji. Wyjaśniał też w swoich tekstach niektóre możliwe reakcje organizmu na spożywanie wody oraz omawiał sposoby radzenia sobie z niektórymi z nich. Wśród zalet pozytywnego wpływu zakładów zdrojowych na pacjenta podkreślał miłą atmosferę i towarzystwo, brak obowiązków i trosk oraz rozrywkę (Pląskowski 1866f, s. 159-160).

Pląskowski popularyzował kąpiele mineralne, morskie i rzeczne. Próbował obalić mit, że dla wszystkich - niezależnie od wieku i płci - zarówno woda słona, jak i słodka ma zbawienne działanie. Niekiedy drobne uchybienia podczas kąpieli mogły, jego zdaniem, prowadzić do utraty zdrowia zamiast do jego poprawy. Przekonywał, że osoby korzystające z tej formy wspomagania organizmu powinny rozważyć jej skuteczność dla siebie. Znaczenie mają bowiem temperatura wody, rodzaj i pora dnia oraz częstotliwość i metoda polewania ciała. Publicysta polecał zapoznanie się z zasadami balneologii i dostosowanie kąpieli do indywidualnych potrzeb (Pląskowski 1869e, s. 155-156). Zarazem autor podkreślał rolę wody w utrzymaniu czystości ciała. W tym celu radził łaźnie parowe, do których mieszkańcy wsi mogli uczęszczać minimum dwa razy w tygodniu. W kwestii kąpieli w zbiornikach wodnych (takich jak stawy, jeziora, rzeki) kładł nacisk na zapewnienie bezpieczeństwa, dlatego wskazywał, że ważne jest odpowienie przygotowanie ich brzegów (Pląskowski 1876, s. 340).

Szczególnie istotne w opinii lekarza było przestrzeganie właściwej diety. Uświadamiał swym czytelnikom, że od składu menu zależy zdrowie człowieka. Duże znaczenie miało również miejsce przechowywania produktów oraz przede wszystkim sposób przygotowania posiłku (Pląskowski 1870a, s. 120). Wpływ na proces trawienny miały poza tym przyprawy dodawane do potraw (m.in. cukier, sól, ocet). W jadłospisie autor dopuszczał dania z surowych owoców i warzyw, jednak podkreślał, że z uwagi na ich kaloryczność mogą stanowić jedynie uzupełnienie diety. Uważał, że menu powinno być bogate w płyny. Nie zalecał spożywania dużej ilości alkoholu, który zamiast gasić pragnienie, pobudzał organizm. Posiłki powinny powstawać w procesie pieczenia i smażenia. Wzorem starożytnych Rzymian zalecał prostotę w sztuce kulinarnej. Niezwykle ważna w jego opinii jest jakość produktów i ich świeżość (Pląskowski 1870b, s. 128; Pląskowski 1870c, s. 144). Pląskowski wskazywał gospodyniom domowym, jakie mięso jest najzdrowsze dla domowników. Nie omijał zagad- 
nienia czynników mających wpływ na jego jakość, takich jak proces hodowli, a przede wszystkim żywienie, wysiłek fizyczny, wiek czy transport i metoda uboju. Ostrzegał przed spożywaniem mięsa zwierząt chorych oraz innych produktów pochodzenia zwierzęcego z takiego źródła. Osobom o delikatnym żołądku radził spożywać mięso lekkostrawne (tj. drób, cielęcinę, króliki, gołębie) i unikać wołowiny. $Z$ mięsa wołowego polecał wybierać części przednie lub zadnie (Pląskowski 1871d, s. 242-243). Proponował umieszczenie w jadłospisie potraw przygotowanych z mózgu zwierzęcego, ozorów, głowizny czy krwi lub flaków. Przekonywał o ich smaku i zaletach zdrowotnych. Przykładowo mózg mogły spożywać osoby chore lub o osłabionym układzie pokarmowym. Z kolei krew wykorzystywano do przyrządzania salcesonów z kaszą i słoniną oraz czerniny - tę zupę zalecał do picia w naturalnej postaci, szczególnie osobom chorym. Smaczne dania można było przygotować z główek cielęcych i ozorów wołowych. Oczyszczone, ugotowane i podane z lekkim sosem na bazie wina, mogły znaleźć się w menu rekonwalescentów. Mniej wyszukanym daniem była tzw. siekanka, wykonana z płuc i wątroby. Pląskowski za wartościowe uznawał wątróbki gęsie, które stanowiły doskonałą bazę pasztetów. Wśród gatunków mięs nie mogło zabraknąć nerek, podawanych w wersji smażonej lub pieczonej. Za jadalne uważał kiszki i flaki. Pierwsze, nadziewane różnorodnym farszem, stanowiły prawdziwy rarytas. Podobnie było z galaretami z nóżek cielęcych i wołowych (Pląskowski 1871e, s. 249-250; Pląskowski 1877a, s. 318-326). Publicysta zabierał głos też w kwestii przygotowywania posiłków, m.in. pieczenia chleba. Osoby mające kłopoty trawienne powinny, jego zdaniem, jadać ten z mąki pszennej, dobrze wypieczony, natomiast dla osób silnych i zdrowych lepszy jest ten wyrabiany z mąki żytniej. Autor podjął dodatkowo zagadnienie higieny wypieku chleba oraz zanieczyszczenia mąki do jego przygotowania (Pląskowski 1873b, s. 491-500). Poza tym podkreślał znaczenie i walory smakowe produktów mlecznych w diecie (Pląskowski 1877b, s. 375-377).

\section{HIGIENA MIESZKAŃ}

Stan sanitarny mieszkań w omawianym okresie był często poddawany krytyce na łamach czasopism. Pląskowski również zaakcentował ten problem w swoich tekstach. Dbałość o bezpieczeństwo budynków mieszkalnych uznawał za cel społeczny każdego państwa, miasta, wsi, gminy oraz ludzi. Z przykrością stwierdzał, że współczesne mieszkania nie spełniały zasad higieny gwarantujących zdrowie. Zauważał, że przedsiębiorcy coraz częściej budowali dla zysku, oszczędnie, łamiąc standardy mieszkaniowe. Rozmieszczenie pokoi, ich rozmiar, oświetlenie i ogrzewanie były nieprawidłowe. Ponadto jakość wykończenia i dostęp do świeżego powietrza pozostawiały wiele do życzenia. Cierpieli na tym mieszkańcy takich lokali. Jego zdaniem każdy człowiek powinien mieć do dyspozycji pomiesz- 
czenie o minimalnej wysokości, szerokości i długości czterech lub pięciu łokci (Encyklopedia Powszechna PWN 1984, s. 802). Publicysta zwrócił też uwagę na to, że dodatkowe meble w dużej ilości czy piece zmniejszają przestrzeń mieszkalną, prowadząc do problemów z oddychaniem, ociężałości i bólu głowy. Nie bez znaczenia jest również temperatura powietrza w pomieszczeniu - nie powinna ona przewyższać $16^{\circ} \mathrm{R}$. Gotowanie, pranie, prasowanie, mycie podłóg, kąpiel, a nawet przygotowanie herbaty dla domowników mogło mieć wpływ na wzrost tej temperatury oraz zwiększać wilgotność powietrza w pokojach. Ponadto duża ilość kwiatów doniczkowych (zwłaszcza w sypialni) oraz osób zamieszkałych w mieszkaniach o małym metrażu wpływała na jakość powietrza. Konieczne w tej sytuacji było stałe wietrzenie pomieszczeń, które zabezpieczało przed pleśnią osadzającą się najczęściej w rogach pokoi lub na ścianach za meblami. Problemy te w dużej mierze wynikały ze złego ogrzewania. Dlatego do osuszenia mieszkań i usunięcia wilgotnego powietrza autor proponował kaloryfery oraz wentylatory (Pląskowski 1866d, s. 80). W domach po remontach radził sprawdzić, czy mury i ściany są suche. Wilgoć mogła bowiem gromadzić się najczęściej w pomieszczeniach usytuowanych na parterze oraz w budynkach bez piwnic, gdzie było jedynie podłoże z gliny. Brak odprowadzenia wody na zewnątrz domu w postaci rur podziemnych także mogło być przyczyną nadmiernej wilgoci. Mogła się ona pojawić w mieszkaniach nawet na najwyższych piętrach. W tej sytuacji powodem mógł być nieszczelny dach, niezabezpieczający przed śniegiem i deszczem ścian budynku. Pląskowski podkreślał, że winę za pojawienie się grzyba czy pleśni w mieszkaniu niekiedy ponoszą sami mieszkańcy, gdy nie dbają ani o właściwe ogrzewanie, ani o wietrzenie pomieszczeń mieszkalnych. W celu usunięcia plam ze ścian radził zastosować bibułę. Jeśli ten sposób był niewystarczający, proponował usunąć je mechanicznie, oskrobać tynk, wyrzucić obicie ścian i następnie pomalować wapnem lub farbą z ałunem.

W kwestii mieszkań Pląskowski ostrzegał przed zatruciem gazem węglowym. W jego mniemaniu najlepsze były piece hermetyczne, zamykające otwór szczelnymi drzwiczkami. Nie tylko skutecznie chroniły przez zaczadzeniem, ale również zabezpieczały mieszkanie przed ogniem. Chcąc nie dopuścić do nagromadzenia szkodliwych gazów, radził ustawić na środku pokoju naczynie z wodą wapienną. Miała ona działanie ochronne i zapobiegawcze. Mieszkańcom podejrzewającym, że w ich pokojach ulatnia się gaz węglowy, polecał prosty sposób - ustawienie zapalonej świecy. Jego obecność miał potwierdzać płomień świecy, który początkowo zmieniał barwę na ciemną, a następnie całkiem gasł. W przypadku zatrucia gazem zalecał natychmiastową pomoc poszkodowanym. Należało

2 Łokieć - jednostka długości określana długością części ręki, zwykle od stawu łokciowego do końca palca środkowego. W Królestwie Polskim od 1819 r. miał 576 mm. 
ich wynieść z miejsca, gdzie ulatniał się gaz lub - jeśli to niemożliwe - otworzyć okna i drzwi. Osoby nieprzytomne należało cucić przez przystawianie im do twarzy chusteczki nasączonej kroplami amoniaku, octu lub kamfory. Oprócz tego proponował wywołać u nich wymioty przy pomocy zwykłego piórka włożonego do gardła. W takich niebezpiecznych sytuacjach apelował, aby przede wszystkim wezwać lekarza. Tym samym uświadamiał, że zatrucie gazem może być śmiertelne (Pląskowski 1866e, s. 91-92; Pląskowski 1876, s. 337-340).

\section{ZAKOŃCZENIE}

Romuald Pląskowski był doświadczonym lekarzem internistą, doskonale obeznanym z sytuacją zdrowotną na ziemiach Królestwa Polskiego. Stał na stanowisku, że szczególnie ważna jest profilaktyka w zapobieganiu chorobom, a przede wszystkim higiena. W trosce o świadomość społeczeństwa polskiego popularyzował wiadomości z tej dziedziny w swoich pracach. Rodziców, nauczycieli i wychowawców informował o zasadach higienicznych, propagował wzorce w zakresie poprawy czystości ciała, odżywiania, warunków życia. Swoje uwagi adresował w szczególności do kobiet, czyniąc je odpowiedzialnymi za rozpowszechnianie tych idei. Mimo tego, że odbiorcą jego artykułów były osoby nieposiadające wykształcenia medycznego, informacje z zakresu higieny prezentował z niezwykłą dokładnością. W swoich tekstach omawiał etapy rozwoju człowieka oraz wyjaśniał procesy, które zachodzą w organizmie. Tym samym starał się kształtować prohigieniczną postawę w społeczeństwie, zmieniać mentalność oraz obalać stereotypy w podejściu do zdrowia.

\section{BIBLIOGRAFIA}

Arabas I. (2006), Apteczki domowe w polskich dworach szlacheckich, Warszawa: Wydawnictwa IHN PAN.

Bojczuk A. (2005), Kronika Towarzystwa Lekarskiego Warszawskiego w latach 1820-1915, [w:] Towarzystwo Lekarskie Warszawskie 1820-2005, cz. 1: 1820-1917, Warszawa: Towarzystwo Warszawskie Lekarskie.

Bołdyrew A. (2016), Społeczeństwo Królestwa Polskiego wobec patologii społecznych w latach 1864-1914, Łódź: Wydawnictwo Uniwersytetu Łódzkiego.

Chojna W.J. (1981), Pląskowski Romuald, [w:] Polski Stownik Biograficzny, t. 26, Wrocław-Warszawa-Kraków-Gdańsk-Łódź: Polska Akademia Umiejętności.

Demel M. (1964), Pedagogiczne aspekty Warszawskiego Ruchu Higienicznego (1864-1914), Wrocław-Warszawa-Kraków: Polska Akademia Nauk.

Demel M. (1980), Pedagogika zdrowia, Warszawa: WSiP.

Encyklopedya Ilustrowana Medycyny i Higieny Popularnej, wedtug dzieła dra P. Bonami, laureata Akademii Medycznej w Paryżu, opracowana i do naszych stosunków zdrowotnych zastosowa- 
na przez dra J. Starkmana (1892), Warszawa: Nakładem Autora, Skład Główny w Księgarni Maurycego Orgelbranda.

Encyklopedia Powszechna PWN (1984), t. 2, Warszawa: PWN.

Encyklopedia Powszechna PWN (1985), t. 4, Warszawa: PWN.

Encyklopedya Powszechna Stanisława Orgelbranda (1863), t. 12, Warszawa: Nakład, druk i własność S. Orgelbranda.

Kośmiński S. (1888), Słownik lekarzów polskich obejmujący oprócz krótkich życiorysów lekarzy Polaków oraz cudzoziemców w Polsce osiadtych, doktadna bibliografię polską od czasów najdawniejszych aż do 1885 roku, Warszawa: Nakład Autora, Skład Główny w Księgarni Gebethnera i Wolfa.

Marek A. (2009), Opieka nad chorym dzieckiem w opinii polskiej prasy medycznej na ziemiach Królestwa Polskiego w latach 1801-1908, Warszawa: Śląski Uniwersytet Medyczny IHN PAN.

Ostrowska T. (1988), Początki ruchu naukowego w medycynie. Akademie, towarzystwa i czasopisma naukowe, [w:] T. Brzeziński (red.), Historia medycyny, Warszawa: Państwowy Zakład Wydawnictw Lekarskich.

Pląskowski R. (1865a), Hygiena kobiet. Odzienie. Moda i kosmetyki, „Bluszcz”, nr 10.

Pląskowski R. (1865b), Hygiena kobiet. Odzienie. Moda i kosmetyki, „Bluszcz”, nr 18.

Pląskowski R. (1865c), Wiadomości z hygieny, „Bluszcz”, nr 2.

Pląskowski R. (1866a), Hygiena kobiet. Głowa, twarz i włosy, „Bluszcz”, nr 23.

Pląskowski R. (1866b), Hygiena kobiet. Gtowa, twarz i włosy, „Bluszcz”, nr 31.

Pląskowski R. (1866c), Hygiena kobiet. Glowa, twarz i włosy, „Bluszcz”, nr 34.

Pląskowski R. (1866d), Hygiena kobiet. Mieszkanie, rozkład domu, jego ogrzanie i przewietrzanie, „Bluszcz”, nr 59.

Pląskowski R. (1866e), Hygiena kobiet. Mieszkanie, rozkład domu, jego ogrzanie i przewietrzanie, „Bluszcz”, nr 62.

Pląskowski R. (1866f), Hygiena kobiet. Wody mineralne, „Bluszcz”, nr 37.

Pląskowski R. (1866g), Hygiena kobiet. Wody mineralne, „Bluszcz”, nr 38.

Pląskowski R. (1866h), Hygiena kobiet. Wody mineralne, „Bluszcz”, nr 39.

Pląskowski R. (1866i), Hygiena kobiet. Wody mineralne, „Bluszcz”, nr 41.

Pląskowski R. (1867a), Hygiena kobiet. Apteczki domowe wiejskie, „Bluszcz”, nr 17.

Pląskowski R. (1867b), Hygiena kobiet. Apteczki domowe wiejskie, „Bluszcz”, nr 41.

Pląskowski R. (1867c), Hygiena kobiet. Apteczki domowe wiejskie, „Bluszcz”, nr 42.

Pląskowski R. (1867/1868), Hygiena kobiet. Apteczki domowe wiejskie, „Bluszcz”, nr 1.

Pląskowski R. (1868a), Hygiena kobiet. Apteczki domowe, „Bluszcz”, nr 30.

Pląskowski R. (1868b), Hygiena kobiet. Apteczki domowe, „Bluszcz”, nr 32.

Pląskowski R. (1868c), Hygiena kobiet. Apteczki domowe, „Bluszcz”, nr 34.

Pląskowski R. (1868d), Hygiena kobiet. Apteczki domowe „Bluszcz”, nr 35.

Pląskowski R. (1868e), Hygiena kobiet. Apteczki domowe, „Bluszcz”, nr 39.

Pląskowski R. (1868f), Hygiena kobiet. Apteczki domowe, „Bluszcz”, nr 40.

Pląskowski R. (1868g), Hygiena kobiet. Apteczki domowe, „Bluszcz”, nr 47.

Pląskowski R. (1868h), Hygiena kobiet. Apteczki domowe, „Bluszcz”, nr 48.

Pląskowski R. (1868i), Hygiena kobiet. Apteczki domowe, „Bluszcz”, nr 49. 
Pląskowski R. (1868j), Hygiena kobiet. Apteczki domowe, „Bluszcz”, nr 51.

Pląskowski R. (1868k), Hygiena kobiet. Apteczki domowe, „Bluszcz”, nr 52.

Pląskowski R. (18681), Hygiena kobiet. Apteczki domowe wiejskie, „Bluszcz”, nr 18.

Pląskowski R. (18681), Hygiena kobiet. Apteczki domowe wiejskie, „Bluszcz”, nr 21.

Pląskowski R. (1868m), Hygiena kobiet. Apteczki domowe wiejskie, „Bluszcz”, nr 22.

Pląskowski R. (1868n), Hygiena kobiet. Apteczki domowe wiejskie, „Bluszcz”, nr 26.

Pląskowski R. (18680), Hygiena kobiet. Apteczki wiejskie, „Bluszcz”, nr 43.

Pląskowski R. (1868p), Hygiena kobiet. Apteczki wiejskie, „Bluszcz”, nr 44.

Pląskowski R. (1868r), Hygiena kobiet. Pielęnowanie zębów, „Bluszcz”, nr 27.

Pląskowski R. (1868s), Hygiena kobiet. Pielęgnowanie zębów, „Bluszcz”, nr 28.

Pląskowski R. (1869a), Hygiena kobiet. O fizycznym wychowaniu dzieci, „Bluszcz”, nr 4.

Pląskowski R. (1869b), Hygiena kobiet. Wychowanie niemowląt, ich kapiele, powijanie, sen i karmienie, ,Bluszcz”, nr 14.

Pląskowski R. (1869c), Hygiena kobiet. Wychowanie niemowląt, ich kapiele, powijanie, sen i karmienie, „Bluszcz”, nr 15.

Pląskowski R. (1869d), Hygiena kobiet. Wychowanie niemowląt, ich kapiele, powijanie, sen i karmienie, ,Bluszcz”, nr 28.

Pląskowski R. (1869e), Wiadomości z hygieny. Kapiele rzeczne i morskie oraz zimne obcierania i zawijania, „Bluszcz”, nr 23.

Pląskowski R. (1870a), Wiadomości z hygieny. Pożywienie człowieka w ogólnem znaczeniu, o ile jest potrzebne i konieczne, „Bluszcz”, nr 16.

Pląskowski R. (1870b), Wiadomości z hygieny. Pożywienie człowieka w ogólnem znaczeniu, o ile jest potrzebne i konieczne, „Bluszcz”, nr 17.

Pląskowski R. (1870c), Wiadomości z hygieny. Pożywienie człowieka w ogólnem znaczeniu, o ile jest potrzebne i konieczne, „Bluszcz”, nr 19.

Pląskowski R. (1871a), O wypadaniu włosów przez dr J. Pincusa, docenta Berlińskiego Uniwersytetu, „Bluszcz”, nr 32.

Pląskowski R. (1871b), O wypadaniu włosów przez dr J. Pincusa, docenta Berlińskiego Uniwersytetu, „Bluszcz”, nr 33.

Pląskowski R. (1871c), O wypadaniu włosów przez dr J. Pincusa, docenta Berlińskiego Uniwersytetu, „Bluszcz”, nr 34.

Pląskowski R. (1871d), Wiadomości z hygieny. Pokarmy mięsne ze względu na ich pożywność, „Bluszcz”, nr 31.

Pląskowski R. (1871e), Wiadomości z hygieny. Pokarmy mięsne ze względu na ich pożywność, „Bluszcz”, nr 32.

Pląskowski R. (1873a), Apteczka domowa, [w:] J.T. Lubomirski, E. Stawski, S. Przystański (red.), Encyklopedya rolnictwa i wiadomości i związek z niem mających, t. 1, Warszawa: Skład Główny w Księgarni Gebethnera i Wolfa.

Pląskowski R. (1873b), Chleb, [w:] J.T. Lubomirski, E. Stawski, S. Przystański (red.), Encyklopedya rolnictwa i wiadomości i związek z niem mających, t. 1, Warszawa: Skład Główny w Księgarni Gebethnera i Wolfa. 
Pląskowski R. (1876), Hygiena ze względu na stosunki wiejskie i choroby endemiczne, [w:] J.T. Lubomirski, E. Stawski, S. Przystański (red.), Encyklopedya rolnictwa i wiadomości i zwiazek z niem mających, t. 3, Warszawa: Skład Główny w Księgarni Gebethnera i Wolfa.

Pląskowski R. (1877a), Mięso, [w:] J.T. Lubomirski, E. Stawski, S. Przystański (red.), Encyklopedya rolnictwa i wiadomości i związek z niem mających, t. 4, Warszawa: Skład Główny w Księgarni Gebethnera i Wolfa.

Pląskowski R. (1877b), Nabiat ze stanowiska hygienicznego, [w:] J.T. Lubomirski, E. Stawski, S. Przystański (red.), Encyklopedya rolnictwa i wiadomości i związek z niem mających, t. 4, Warszawa: Skład Główny w Księgarni Gebethnera i Wolfa.

Podgórska-Klawe Z. (2005), Warszawa i jej instytucje medyczne, [w:] Z. Podgórska-Klawe (red.), Towarzystwo Lekarskie Warszawskie 1820-2005, cz. 1: 1820-1917, Warszawa: Towarzystwo Warszawskie Lekarskie.

Ś.P. dr Romuald Pląskowski (1896), „Biesiada Literacka”, nr 28.

Ś.P. Romuald Pląskowski (1896), „Wędrowiec”, nr 27.

Wielka Encyklopedya Powszechna Ilustrowana (1902), t. 29, Warszawa: Drukarnia Aleksandra Jezierskiego.

\section{SUMMARY}

Romuald Pląskowski's hygiene guidelines were addressed specifically to women. He considered them responsible for health education of children and for running the house in accordance with the hygiene rules. Pląskowski dealt with problems related to the nursing of children. He advised on bathing, clothing, feeding, sleeping and physical development issues. Moreover, he educated women on how to take care of their own health to enjoy it as long as possible and introduced secrets of a diet and methods of preparing meals. Pląskowski drew attention to the contents of the home medical cabinet, including home-made herbs and infusions. He also emphasized the impact of living conditions on the health of the family.

Keywords: hygiene; health; diet; woman; upbringing; Romuald Pląskowski 